\title{
Content Equivalence Analysis of Health News Translation: A Bakerian Approach
}

\author{
Maryam Gharedaghi \\ Department of English Language and Translation Studies, Islamic Azad University Parand- Robat Karim Branch, \\ Parand, Iran \\ Razieh Eslamieh \\ Department of English Language and Translation Studies, Islamic Azad University Parand- Robat Karim Branch, \\ Parand, Iran
}

Hamid Reza Shahidi

Department of English Language, Islamic Azad University Garmsar Branch, Tehran, Iran

\begin{abstract}
The primary purpose of the present paper is to investigate content equivalence in the English to Persian translation of General Health News based on Baker's model. A descriptive qualitative study was designed and 10 texts from English and Farsi versions of Iran Newspaper were randomly selected. To assess the translation quality of the selected texts, the researcher compared the original and translated texts at word, phrase and sentence level and tabulated the obtained data and estimated the frequency and percentage of translation inadequacies. The results revealed that most errors in the English translations were rooted in the textual domain where the translators have misunderstood the general concept of the source context. This was followed by semantic errors. The third place was given to the errors in the pragmatic domain which mainly addressed the purpose and meaning of the concepts presented in the source language. The least frequently occurred errors were related to grammatical errors which mainly covered prepositions and tenses. Research on content equivalence, in general, can help experts assess the quality of the translated text. Research on content equivalence of particular texts can lead to detecting translation problems, translation errors and translation inadequacies in that particular field.
\end{abstract}

Index Terms - semantic equivalence, grammatical equivalence, pragmatic equivalence, textual equivalence, content equivalence, health news, Mona Baker

\section{INTRODUCTION}

Finding the proper equivalence is a concern of every translation process as "the discipline of translation studies suggests that full equivalence in translation between languages is rare" (Forutanian \& Chalak, 2013, p.2). However, finding the proper equivalence in the process of translation of General Health News seems to be much more demanding, as accuracy of language is crucial in health language (Taylor 2005). Inappropriate translation of such texts can endanger many lives henceforth it is of utmost importance that translators of health texts "avoid jargon, be accurate in what they say, and be careful with abbreviations and acronyms" (Taylor, 2005, p.105).

The main concern is how to translate non-equivalence health technical terms when such terms do not have equivalence in the target language due to the fact that mistranslation may lead to misunderstanding of the whole content. The unlucky point is that, many pieces of Health News are translated by non-professional translators working part-time in the newspapers and as they would like to translate as many pages as possible in a relatively short period of time, they employ deletions and additions (Taylor 2005). Such translation strategies for rendering scientific and technical health terminology decreases the quality of the translated text and above all may lead to the lack of transference of the main content encoded in the ST.

The present study aims to investigate content equivalence in General Health News based on Bakerian (2010) model of equivalence which considers content equivalence in terms of textual, semantic, grammatical, and pragmatic equivalence. The research means to find the extent to which semantic, grammatical, textual and pragmatic equivalences are accurately rendered in English to Persian translation of General Health News? What are the most-frequently-used and the least-frequently-used equivalences in the English to Persian translation of General Health News? And which translation paradigm is followed in the English to Persian translation of general health news texts?

In this regard the study is delimited to the texts of Health News of IRNA News Agency and Iran Newspaper rather than including different news agencies and newspapers. Moreover, the research is delimited to content equivalence and four aspects of Baker's (2010) model (semantic, grammatical, textual, and pragmatics).

\section{THEORETICAL FRAMEWORK}


The idea of equivalence structures the premises of many theories of translation and has been one of the controversial issues in recent decades as it helps both the proper translation of a text and the proper assessment of the translated text. As House (2015) asserts "a theory of translation is not possible without a reflection on the role of one of its core concepts, i.e. equivalence in translation and it is the conceptual basis of translation quality assessment" (p. 1).

Numerous linguistic scholars recognized the importance of seeking the proper equivalence during translation process. Halverson (1997) has defined equivalence as the relation of two existences and the relation is described by the number of potential properties of one of the similarities. House (1997) states the notion of equivalence is the conceptual basis of translation. Catford (1996) states that finding TL equations, are the main problem of translation and the main task of translation theory is to determine the nature and conditions of equivalence. Pim (2017) argues that translation equivalence is the similarity between a word (or expression) in one language and its translation in another. This similarity results from overlapping ranges of reference. Hence, it could be concluded that a translation equivalent is a corresponding word or expression in another language. Though Pym's (2017) definition of translation equivalence is acceptable, it seems formalistic as it does not cover various syntactic, semantic, pragmatic, and textual strata of language. Baker's definition and theories of equivalence (2010) which encompass all these areas seem to be more comprehensive than the other previously suggested models.

Baker offers a more detailed list of conditions upon which the concept of equivalence can be defined (Leung 2016). Her model of equivalence was first proposed in 1992. She explored the concept of equivalence at different levels in relation to the translation process, including various aspects of translation. She also integrated the linguistic and communication approach. Baker (1992) stipulates that detecting equivalents in translation includes decoding the source language (SL) text and trying to discover an appropriate equivalent in the Target Language (TL) text. She further explains that equivalent dominates over all linguistic units such as words, morphemes, proverbs, phrases, idioms, and clauses.

To be more precise, she distinguishes between a word-level and above-world level equivalence. Adopting a bottomup approach, she began with simple terms and continued with a bottom-up approach with grammatical, textual, semantic and practical equations. Baker puts emphasis on the significance of individual words in the process of translation because words as single units draw the translator's attention at the first step. Baker argues that words are of a complex nature so that sometimes a single word in different languages may have different meanings. Therefore, parameters such as number, gender, and stress must be taken into account when translating a word. In the same line of argumentation, Baker (1992) declares that translation equivalence can be explored through grammatical, textual, semantic and pragmatic equivalence. These factors come to shape content equivalence.

Baker defines grammatical equivalence as diversity of grammatical categories across languages is a significant factor and Grammar rules tend to vary across languages, and this can cause problems in communication. In fact, different SL and TL grammatical structures may lead to dramatic changes in the way information or messages are transmitted. These changes may cause the TL translator to add or delete information in the TT due to the absence of specific command-line devices in the TL itself. Among these grammatical tools that may lead to translation problems, Baker focuses on number, stress, sound, person, and gender (Baker 1992).

Pragmatic equivalence refers to consequences and strategies of avoidance during the translation process. Consequences are not about what is explicitly said rather they are about what is implied. Therefore, the translator needs to make explicit the implied meanings in translation in order to transfer the ST message. The translator must translate the author's intentions into another culture so that the TC reader can fully and clearly understand the meaning (Baker 1992).

Semantic equivalence can be created at word level or above word level. In a bottom-up approach, semantic equivalence is the first element to be considered by the translator. In fact, when interpreting ST analysis, the translator considers words as single units. Baker provides the definition of a word because a single word in different languages may have different meanings. She considers that word is a more complex unit or a new form. This means that the translator must take into account a number of factors when analyzing a single word such as number, gender, and stress (Baker 1992).

Textual equivalence refers to the equivalence of a SL text with a TL text in terms of consistency and information. It provides useful guidance for understanding and analyzing ST Offers. And it can guide the translator in producing a coherent text for TC audiences in a particular context. The translator's task is to choose whether or not to maintain coherent links. His choice is based on three main factors: the target audience, the translation target, and the type of text (Baker 1992).

Baker's analysis on word level is particularly clear and easy to comprehend. Many linguistic scholars and researchers support Baker's theory of equivalence at the word level. Theorist Behar (2007) acknowledges the importance of level 2 quality. Leonardi (2000) introduces Baker's theory as "an extremely interesting discussion of the notion of equivalence" (p. 7). Leonardi is on the belief that Baker's approach puts together the linguistic and the communicative approach. Ghadi (2009), in "Translation Equivalence and Different Theories", addresses Baker's inequality at the word level and considers it as the basic theory before addressing the inequality between English and Persian. In his research, Baker's complete inequality at word level with other approaches has been thoroughly introduced and analyzed as a way of validating this theory. A host of other theorists, researchers, and linguists have emphasized the importance of Baker's 
theories. In the following the applicability of her content equivalence on quality assessment of General Health News translation is studied.

\section{METHODS}

\section{A. Corpora}

Ten Health News texts from Iran Newspaper which were translated from English to Farsi from January to February 2018 comprise the corpora of this study. The minimum length of texts was 10 lines (150 words). The texts mainly provided the readers with recent information concerning the newly released health issues, especially the information people are in need of. The texts covered various concepts such as diabetics, genetic data, smart Nano-medicine for curing cancer cells, crying clubs, seasonal depression, heart attack, top fashion and beauty choices that can make you look older, immune systems, old infections to keep you healthy, and ways to prevent acid reflux.. The texts were selected from Iran Newspaper, because this newspaper is one of oldest and most reliable newspapers in Iran. Moreover, Iran Newspaper releases daily and breaking news about health problems. The newspaper also triumphs on a large number of audiences among scholars and experts in Iran.

\section{B. Procedure}

Ten texts of Health News were randomly selected from Iran Newspaper. The researcher compared and contrasted the original English texts versus their Farsi translations to find translation non-equivalences. Next two raters who were professional translators confirmed the results. To score the translations, the raters compared and contrasted the text items based on Baker's model of translation equivalence (2010) which considers equivalence at semantic, grammatical, textual, and pragmatics levels. The number and category of errors for each text were specified and tabulated; the less the number of errors the better the translation. Tables 3.2.1 and 3.2.2 clarify the procedure.

TABLE 3.2.1

PROCURER IN PRACTICE

\begin{tabular}{|c|c|c|c|c|}
\hline \multicolumn{2}{|l|}{ English Text } & \multicolumn{3}{|l|}{ an Text } \\
\hline \multicolumn{2}{|c|}{$\begin{array}{l}\text { Five Things Everyone Needs To Know About Seasonal } \\
\text { Depression } \\
\text { For me, winter is not the most wonderful time of the year. In fact, } \\
\text { it's the worst. The biting cold, the cloudy days, being stuck inside - } \\
\text { every winter, I suffer seasonal depression and I'm not alone. Almost } \\
10 \text { million Americans suffer seasonal depression, otherwise known } \\
\text { as seasonal affective disorder, each year. This is what you need to } \\
\text { know. }\end{array}$} & \multicolumn{3}{|c|}{ 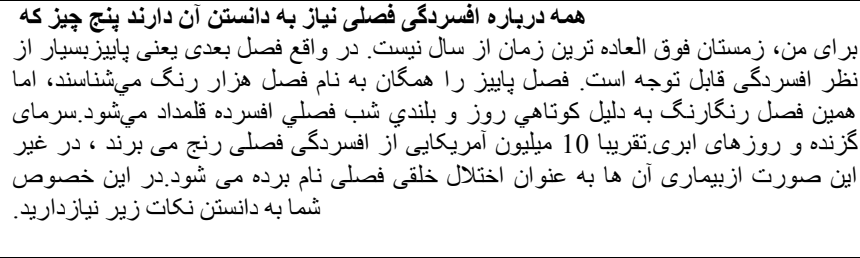 } \\
\hline \multicolumn{2}{|c|}{$\begin{array}{l}\text { 1. It's not funny. } \\
\text { Seasonal depression is not the reason for someone's bad mood. "It's } \\
\text { cloudy so the boss is bitchy." This is a severely false narrative. } \\
\text { Depression is real and manifests itself in numerous ways. It's } \\
\text { nothing to joke about. It's a serious health problem. }\end{array}$} & \multicolumn{3}{|c|}{ 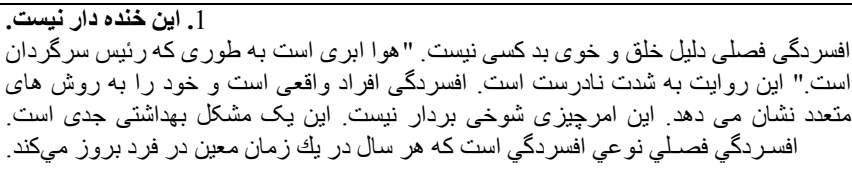 } \\
\hline \multicolumn{2}{|c|}{$\begin{array}{l}\text { 2. It's not just about bad weather. } \\
\text { Often, SAD is just a cyclical, seasonal accent to clinical depression } \\
\text { and bipolar disorder. }\end{array}$} & \multicolumn{3}{|c|}{ 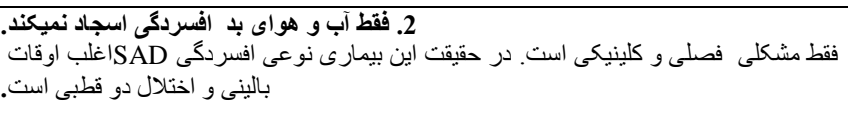 } \\
\hline \multicolumn{2}{|c|}{$\begin{array}{l}\text { 3. You can treat SAD. } \\
\text { Light therapy is considered the gold standard for treating SAD. } \\
\text { This method gives people artificial sunlight and can help correct } \\
\text { circadian rhythms and create feel-good hormones. In addition to } \\
\text { light therapy, other types of depression treatments may be needed. }\end{array}$} & \multicolumn{3}{|c|}{ 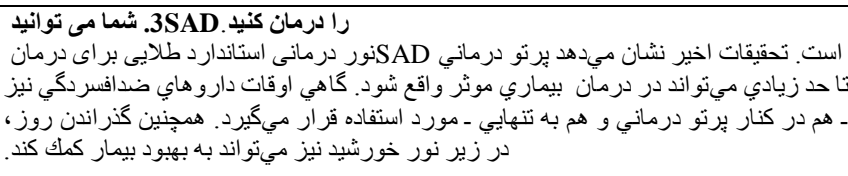 } \\
\hline \multicolumn{2}{|c|}{$\begin{array}{l}\text { 4. SAD can be debilitating. } \\
\text { Depression isn't just about feeling sad. It can be debilitating. Even } \\
\text { the most mundane, simple things can feel like an incredible chore. }\end{array}$} & \multicolumn{3}{|c|}{ 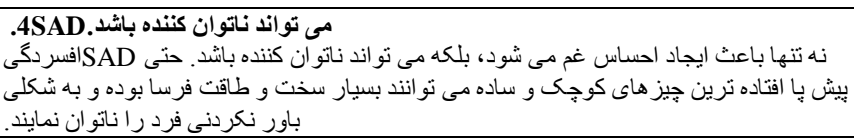 } \\
\hline \multicolumn{2}{|c|}{$\begin{array}{l}\text { ou would any other mental } \\
\text { condition. It's not some } \\
\text { disorder. }\end{array}$} & \multicolumn{3}{|c|}{ 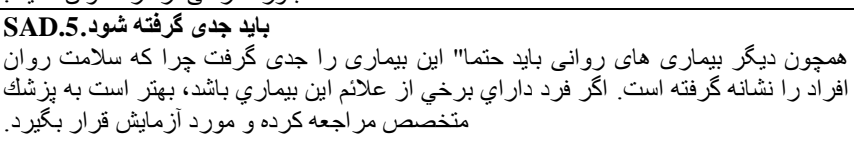 } \\
\hline \multicolumn{2}{|l|}{245 words } & \multicolumn{3}{|c|}{404 words } \\
\hline \multicolumn{3}{|c|}{ Target text } & \\
\hline & & & \\
\hline & & & & \\
\hline$-e$ & \multicolumn{2}{|c|}{ فصل باييز را همكان بهاسنام، فصل هزار رنغى } & & \\
\hline & \multicolumn{2}{|c|}{ 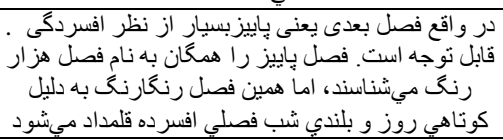 } & addition & extual \\
\hline $\begin{aligned} . \text { otherwise } \mathrm{k} 1 \\
\text { diso }\end{aligned}$ & \multicolumn{2}{|c|}{ 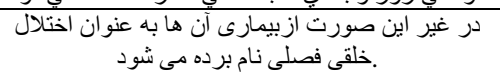 } & deletion & ntic \\
\hline
\end{tabular}




\begin{tabular}{|c|c|c|c|}
\hline It's not funny. & اين خنده دار نبست & Local error & grammatical \\
\hline It's cloudy so the boss is bitchy & ـهو ا ابرى است به طورى كه رئيس سركردان است. & Global error & grammatical \\
\hline It's a serious health problem. & اين يكى مشكل بهداشتى جدى است & Local error & $\begin{array}{l}\text { Semantic } \\
\text { /textual }\end{array}$ \\
\hline -------------- & 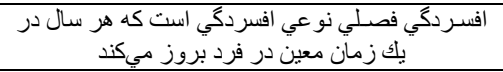 & addition & textual \\
\hline $\begin{array}{l}\text { This method gives people artificial sunlight } \\
\text { and can help correct circadian rhythms and } \\
\text { create feel-good hormones. }\end{array}$ & 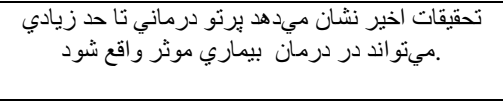 & $\begin{array}{l}\text { Misinterpretation } \\
\text { /reduction }\end{array}$ & textual \\
\hline Depression isn't just about feeling sad. & نه تنها باعث ايجاد احساس غم مى SAD|فسردكى & Global error & grammatical \\
\hline Because it's a serious condition. & جر ا كه سلامت روان افر اد ر ا نشانه كرفنته است & Local error & textual \\
\hline $\begin{array}{l}\text { Even the most mundane, simple things can } \\
\text { feel like an incredible chore. }\end{array}$ & 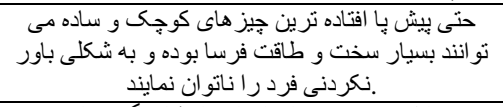 & Addition/local error & semantic \\
\hline Because it's a serious condition. & جر ا كه سلامت روان افر اد ر ا نثانه كر فته است & Addition/local error & textual \\
\hline $\begin{array}{l}\text { It's not some trivial problem. It's part of a } \\
\text { much larger disorder. }\end{array}$ & 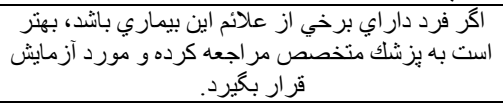 & $\begin{array}{l}\text { Mistranslation } \\
\text { Global error }\end{array}$ & pragmatic \\
\hline ------- & علائم اين بيماري & addition & textual \\
\hline
\end{tabular}

The mistranslated phrases or words are specified in the table. Contrastive analysis of the text based on Baker's model by the two experts is presented in Table 3.2.

TABLE 3.2.2

CRITERIA OF BAKER'S CONTENT EQUIVALENCE ANALYSIS

\begin{tabular}{|c|c|c|c|c|}
\hline Equivalence Type & Description & Rtaer1 & Rater2 & Mean \\
\hline Semantic & $\begin{array}{l}\text { Meaning deviation at word level and above word level, when translating } \\
\text { from one language into another. }\end{array}$ & 5 & 6 & \\
\hline Grammatical & Diversity of grammatical categories across languages is observed. & 3 & 3 & \\
\hline Textual & $\begin{array}{l}\text { The equivalence between a SL text and a TL text in terms of information } \\
\text { and cohesion is not met. }\end{array}$ & 8 & 8 & \\
\hline Pragmatic & Something implied is not translated or mistranslated. & 1 & 0 & \\
\hline
\end{tabular}

The two rates almost agreed on the number and types of errors. The translated text had no pragmatic error. However, the semantic problems could not be ignored as both experts marked 5 to 6 semantic errors. The raters marked 3 grammatical errors and 8 textual errors. It can be concluded that the translator could not present a grammatically wellformed, fluent, and organizationally acceptable translation of the text from English to Farsi. Semantically speaking the text requires editing. It is worth mentioning that the English text has 245 words in 27 sentences, while the Farsi translation includes 404 words and 31 sentences. It seems that the translator preferred a target oriented translation with high degree of naturalness, but has mistranslated, deleted or added 17 items.

\section{RESULTS}

Translation assessment based on the above-mentioned procedure was carried out on ten texts to reach the answers of the previously formulated research questions.

\section{A. Research Question One}

To what extent are semantic, grammatical, textual and pragmatic equivalences accurately rendered in English to Persian translation of General Health News?

Table 4.11 indicates the number of all errors in the selected texts. According to the table, it can be indicated that equivalence is a concept that needs further attention in English to Persian translation of Health News.

TABLE 4.11

EQUIVALENCE ANALYSIS IN TEN TEXTS

\begin{tabular}{|c|c|c|c|c|c|c|c|c|c|c|c|}
\hline Type of Equivalence & \multicolumn{9}{|c|}{ No. of passages } \\
\hline & $\mathbf{1}$ & $\mathbf{2}$ & $\mathbf{3}$ & $\mathbf{4}$ & $\mathbf{5}$ & $\mathbf{6}$ & $\mathbf{7}$ & $\mathbf{8}$ & $\mathbf{9}$ & $\mathbf{1 0}$ & \multicolumn{1}{|c|}{ Meal } \\
\hline Semantic & 9 & 14 & 10.5 & 4 & 7 & 5.5 & 9 & 11 & 8.5 & 8 & 8.65 \\
\hline Grammatical & 3.5 & 4 & 5 & 2.5 & 6.5 & 2.5 & 6.5 & 9.5 & 7 & 7 & 5.4 \\
\hline Textual & 9.5 & 18.5 & 11.5 & 4.5 & 10.5 & 3 & 7.5 & 5.5 & 10.5 & 10 & 9.1 \\
\hline Pragmatic & 6 & 4.5 & 7 & 1 & 7 & 1.5 & 10 & 15 & 12.5 & 13 & 7.75 \\
\hline
\end{tabular}

As it is evident, the number of textual errors outweighs the number of other types of errors. This is followed by semantic, pragmatic, and grammatical errors, respectively. Accordingly it can be concluded that Health News have been translated moderately weak as the total number of all types of errors is somehow high. Figure 4.11 represents a visual 
model of the analysis conducted for the 10 selected texts.

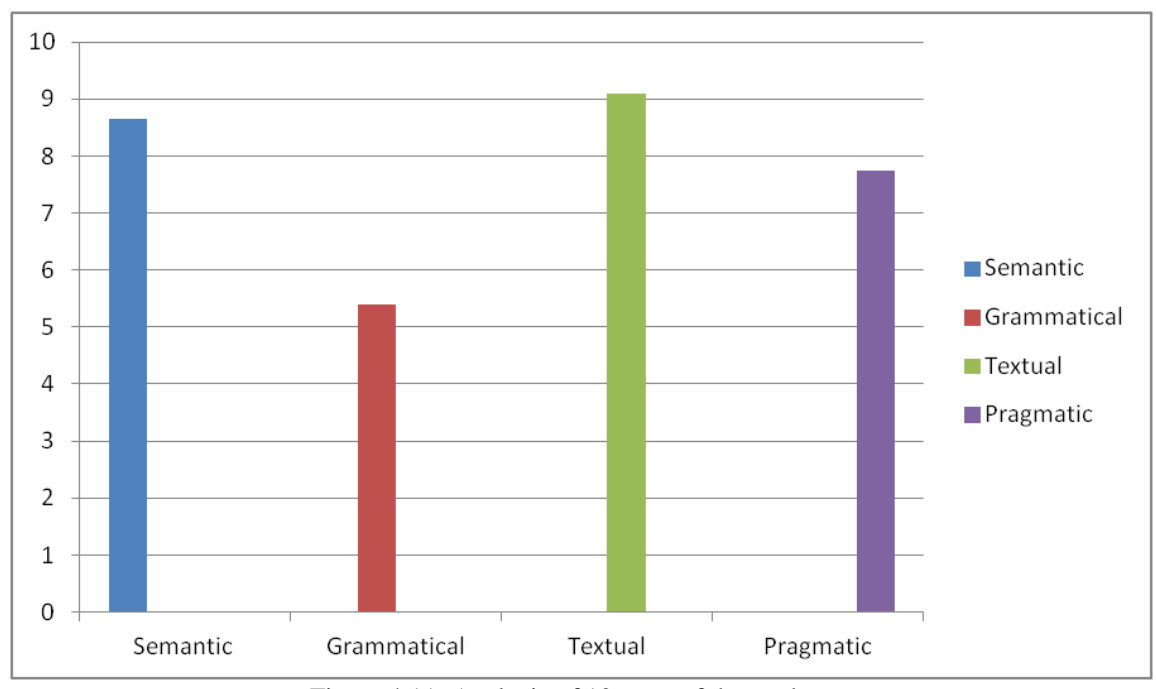

Figure 4.11, Analysis of 10 texts of the study

\section{B. Research Question Two}

What are the most-frequently-used and the least-frequently-used equivalences in the English to Persian translation of General Health News?

As indicated in Table 4.11 and Figure 4.11, grammatical equivalence seems to have received more attention in comparison with other types of equivalence $(\mathrm{m}=5.4)$; however, this is only in comparison with other types of equivalence such as semantic, textual, and pragmatic. It implies that equivalence is a translation problem in Health News.

\section{Research Question Three}

Which translation paradigm is followed in the English to Persian translation of General Health News?

As indicated, the number of textual errors was higher than the other types of errors $(m=9.1)$. The next error semantic error with a mean of 8.65. Pragmatic equivalence comes next with a mean of 7.75 which is somehow high as Health News are expected to be translated with more precision. Grammatical equivalence errors seem to be less than other types $(\mathrm{m}=5.4)$.

\section{DISCUSSION AND FINDINGS}

The Analysis of the data revealed that the most frequent type of error in the English to Farsi translation of Health News was textual equivalence. According to Baker (2010), this category of error includes the situation in which equivalence between a SL text and a TL text in terms of information and cohesion is not met. The second problematic issue for the Persian translators of English, was semantic error with a mean of 8.65 which was followed by the pragmatic equivalence error which included omissions or mistranslations in the target text. The least frequent type of error was grammatical equivalence. Although, the mean was not low, in comparison with other categories, grammatical equivalence seemed to receive the lowest equivalence error with a mean of 5.4.

The findings are in line with some of the previously reported research in the domain of Contrastive Analysis (CA) and Error Analysis (EA). Krčmová's (2004) PhD dissertation reported in his book entitled A contrastive study of nonfiction (expository) texts in Czech Republic focused on the junior students' translations from English to Czech and like the present study, revealed that most of the EFL learners had semantic errors in their translations.

The findings of the present study are also in line with Gile's (2004) study presented in his paper entitled "Translation research versus interpreting research" which concentrated on translation kinship, differences and prospects for partnership. He also found that semantic errors were witnessed among the translation of ESL translators in France where the participants were supposed to translate from English to French. It seems that like Iranian students of English the French ESL learners have some semantic problems. Of course, in some of the texts Iranian translators had better performance than in some other ones in terms of semantic issues. The reason might lie in the nature of those texts. The similarity between the results of this study and Gile's (2004) in terms of semantic issues of the translated texts signifies that mastery over lexicon of English, specifically Health Terminology, is not easy. The reason might also be sought in the ability and experience of translators. Novice translators mainly rely on bilingual dictionaries and in many cases they cannot decipher the meaning from the texts and contexts. Few translators use monolingual dictionaries, very few are armed with enough background knowledge to use the words, phrases, idioms, and terms appropriately.

The present study findings can also take support from Keshavarz and Alimadadi Zonoozi's (2011) study reported in 
their paper entitled "Manipulation of ideology in translation of political texts". Based on the paper, the most frequently occurred error by Iranian translators of English texts are pragmatic errors which might lead to contextualization errors. The reason might lie in the lack or shortage of inter-language pragmatic knowledge of Iranian translators and EFL learners. Translators might not be well aware of the content, purpose, and agenda of issues discussed in the text. To clarify the point more, health and healthcare texts are of different genres. As these texts enjoy different difficulty level, the translators dealing with one type necessarily cannot translate the other types well. That is why some texts receive a good score and enjoy high quality while some others are weak in terms of quality.

The findings of the present study are also in line with Mateo's (2015) study which ran a contrastive multimodal analysis of two Spanish translations of a picture book. He also found that semantic errors might ruin the meaning of the surce texts. Though, a lot of translation theories assert that naturalness and equivalent effect are the two significant factors representing a good translation (Munday, 2016; Nida, 2004), we cannot ignore the role of semantic equivalents, especially when technical terms are mistranslated. As technical terms carry meaning and specify an intention, their mistranslation can ruin the text. That is why translators who render from their own language to another one should be well aware of the semantic value of the terms used in the texts.

Some researchers maintain that translation quality assessment is a kind of evaluation that fills the gap between the presented theories under the title of translation studies and the bulky collection of translation produced in daily life (Bernacka, 2012; Cheng, 2014; Mateo, 2015; Munday, 2016). The present study found that translation of health texts from English to Persian does not meet the expectations of the academic people. The present study tried to take a humble step forward by focusing on the very gap mentioned above.

Equivalence assessment, is an effective tool in the hands of professional translators, their clients, translation researchers and trainee translators. Quality is a competitive weapon, i.e. good quality of translation pays off in higher profits, reduces costs and speeds up time-to-market (Pym, Malmkjær, \& Plana, 2013). Nerudova (2012) asserts that "without equivalence assessment, improving quality of translation is impossible" (p. 8). Equivalence assessment can provide a way to quantify or qualify a process objectively and also is a means for increasing readers' satisfaction.

A very significant point found in the analyzed translations In error classification, a high percentage of deletions indicates that Persian vocabulary formations rules are different from English. In terms of using discourse markers, while the discourse markers such as on the other hand, while, whereas, however, nevertheless, mind you, still, yet, in spite of this, irrespective of the fact that, moreover (very formal), furthermore (formal), in addition, and the like play a significant role in the English texts. English language offers a variety of markers and connectors such as along with, as well as, and, in addition, moreover, furthermore, accompanied by and a host of other. The translators should decide which one suits the target text. In fact, as the analyses of the error types revealed Persian translators doing the translation of Persian texts to English have no choice but adding these discourse markers and in many cases their additions are not to the point. Most of the times, the translators of the texts had to omit or add some words to the Persian text to present more clarification, because of the lack of appropriate equivalence or the lack of knowledge about the discourse markers and connectors. In fact, deletion and addition are the most frequently occurred errors.

Literal translation is another common error. It again indicates the limited number of discourse markers in Persian. Although trivial, it is proven by the fact that Persian translators have imported many discourse markers from English, directly and without change in their previous experiences and now when they are to translate from Persian to English, they do vise-versa and use a lot of discourse markers which might not be necessary in today's English language. An example is the overuse and misuse of the "with regard to, subject to the condition that, nevertheless, as well as that, on top of that (informal), another thing is, what is more, and in spite of the fact that". Munday (2016) implies that when the target text number of words is strangely more than the source text words, it is likely that the translator has not been proficient in the target language as s/he has used a lot of expansions and additions through employing irrelevant discourse markers and tautologies (p.121).

The results confirmed "translating health text as it sounds is not easy. The diverse text features make this genre a unique context. With regard to markers, technical words and terms, various sources and events that can help the audience understand the message better: "A good translation should be effective and convey the same meaning." (Kiraly, 2014, p.31).

\section{REFERENCES}

[1] Albin, V. (1999). Handling Greek and Latin terms in Spanish health translation. Translation Journal, 3 (3), 19-26.

[2] Al-Ghamdi, R. S. (2015). Translation as a three-dimensional phenomenon: A proposed definition. Arab World English Journal, 6(2), 275-286.

[3] Alousque, I. N. (2015). The role of cognitive operations in the translation of film titles. Procedia-Social and Behavioral Sciences, 2(12), 237-241.

[4] Al-Zubi, I. (2012). Difficulties that M.A. students encounter in translating political expressions from his majesty king Abdullah's our last best chance. Master Thesis, Middle East University, Jordan. www.meu.edu.jo/.../Difficulties\%20that\%20M.A\%20Stu. . Retrieved November, 10, 2018.New York.

[5] Aminiha, A. A. (2007). The impact of general English and ESP knowledge on translation of health sciences texts. Master's Thesis of Islamic Azad University-South Tehran Branch, Tehran, Iran. 
[6] Amiri, M., \&Taghipour, S. (2014). Translation competence of Iranian students majoring in English translation: A write aloud protocol. American Journal of Scientific Research, 103, 49-59.

[7] Atkinson, D. (1997). A critical approach to critical thinking in TESOL.TESOL Quarterly, 31(1), 71-94.

[8] Azabdaftari, B. (2013). An explication of concordance between man's mental structure and the narrative structure in the light of Vygotsky's SCT. Iranian Journal of Language Teaching Research, 1(3), 45-51.

[9] Azin, N., \& Heidari Tabrizi, H. (2016). The relationship between critical thinking ability of Iranian English translation stu dents and their translation ability. Theory and Practice in Language Studies, 6(3), 541-548.

[10] Baker, M. (1992). In other words: A course book on translation. New York: Routledge.

[11] Baker, M. (2001). Investigating the language of translation: A corpus-based approach. In P. Fernández Nistaly \& J.M. Bravo Gozalo (Eds.), Pathways of translation studies pathways of translation studies (pp. 47-56). Valladolid: Centro Buendía.

[12] Baker, M. (2010). Critical readings in translation studies (1st ed.). New York: Routledge.

[13] Baker, M. (2011). In other words: A course book on translation (2nd ed.). London: Routledge.

[14] Balliu, C. (2010). Le traducteur, le médecin et le patient. Meta: Journal des Traducteurs, 55 (1), 15-22.

[15] Bayar, M. (2007). To mean or not to mean. Kadmous cultural foundation. Damascus, Syria: Khatawat for publishing and distribution.

[16] Bell, R. T. (1991). Translation and translating. London and New York: Longman.

[17] Berghammer, G. (2006). Translation and the language (s) of medicine: Keys to producing a successful German-English translation. The Write Stuff, 15(2), 40-44.

[18] Bernacka, A. (2012). The importance of translation studies for development education. Policy \& Practice: A development Education Review, 14, 110-115.

[19] Binh, P. T. (2010). Strategies to deal with non-equivalence at word level in translation. (Master's thesis, Hanoi University).

[20] Byrne, J. (2006). Technical translation: Usability strategies for translating technical documentation. New York: Springer.

[21] Catford, J. C. (1996). A Linguistic Theory of Translation. London: Oxford University press.

[22] Chalak, A., \& Forutanian, S. (2013). Equivalence in technical texts: The case of Accounting terms in English-Persian dictionaries. International Journal of Foreign Language Teaching \& Research, 1(3), 26-33.

[23] Cheng, C. (2014). A contrastive study of English and Chinese book reviews on linguistics: Perspective of attitudinal meanings. Theory and Practice in Language Studies, 4 (5), 1009-1016.

[24] Cohen, D. (2005). Mind your language. British Health Journal, 337 (7675), 936-937.

[25] New York, Crombie, A. C. (1967). Medieval and early modern science. Harvard University Press.

[26] Logrono, de Mendoza Ibáñez, F. J. R., \& Masegosa, A. G. (2014). Cognitive modeling: A linguistic perspective (vol. 45). John Benjamins Publishing Company.

[27] Ehsani, F., \& Zohrabi, K. (2014). Assessing translation of advertising text (English-persian) based on House's functionalpragmatic model of TQA. Procedia-Social and Behavioral Sciences, 9(8), 420-424.

[28] Esohe Mercy, O. (2006). English-Edo health translation. Perspectives: Studies in Translatology, 13 (4), 268-277.

[29] Farrokh, P. (2011). The equivalence and shift in the Persian translation of English complex sentences with wh-subordinate clauses. English Language and Literature Studies, 1(2), 74-81.

[30] Forutanian, S., \& Chalak, A. (2013). Equivalence in technical texts: The case of accounting terms in English-Persian dictionaries. International Journal of Foreign Language Teaching \& Research, 1 (3), 1-8.

[31] Ghadi, A. S. (2010). Translation equivalence and different theories. Retrieved from http://e-articles.info/e/a/title/TranslationEquivalence-and-Different-Theories-/ Retrieved October, 07, 2018.

[32] Gholami, M., \& Tajalli, M., \& Shokrpour, N. (2014). An investigation of metadiscourse markers in English health texts and their Persian translation based on Hyland's model. European Journal of English Language and Literature Studies, 2(2), 1-41.

[33] Gholipour, L. (2016). Toury's norms in Persian translation of health papers: A corpus-based study. (Master's Thesis, Islamic Azad University, Science and Research Branch, Tehran, Iran).

[34] Gile, D. (2004). Translation research versus interpreting research: Kinship, differences and prospects for partnership. Translation Research and Interpreting Research: Traditions, Gaps and Synergies, 2(1), 10-34.

[35] Giménez, A. P. (2005). Translation-strategies use: A classroom-based examination of Baker's taxonomy. Translators' Journal, 50(1), 294-311.

[36] Grice, H. P. (1975). Logic and conversation. Syntax and semantics III: Speech Acts. Morgan. New York, Academic Press.

[37] Haliday, M. A. K. (1995). An introduction to functional grammar. London.: Edward Arnold.

[38] Halliday, M. A. K. (1985). Language, context and text. Oxford: Oxford University Press.

[39] Halverson, S. L. (1997). The concept of equivalence in translation studies: Much ado about something. Target. International Journal of Translation Studies, 9(2), 207-233.

[40] Hann, M. (1992). The key to technical translation: Concept specification. Philadelphia: John Benjamins.

[41] Harper, D. (2010). Retrieved from Online Etymology Dictionary: http://www.etymonline.com/ Retrieved May, $27,2017$.

[42] Herget, K., \& Alegre, T. (2009). Translation of health terms. Translation Journal, 13 (3), 44-49.

[43] Hervey, S. G., Higgins, I., \& Haywood, L. M. (1995). Thinking Spanish translation: A course in translation method, Spanish to English. London: Routledge.

[44] Horbačauskienè, J., Kasperavičienė, R., \& Petronienė, S. (2016). Issues of culture specific item translation in subtitling. Procedia-Social and Behavioral Sciences, 2(31), 223-228.

[45] House, J. (1997). Translation quality assessment: A model revisited. Tübingen: Gunter Narr Verlag.

[46] House, J. (2015). Translation quality assessment. Past and present. Routledge Publishing.2014

[47] Hyland, K. (2005). Metadiscourse: Exploring interaction in writing. London: Continuum.

[48] Ivanova, T., \& Arzhantseva, N. (2015). Translation of German and English human-denoting compound nouns into Russian. Procedia-Social and Behavioral Sciences, 18(6), 1248-1254.

[49] Jahanshahi, M., \& Kafipour, R. (2015). Error analysis of English translation of Islamic texts by Iranian translators. Journal of Applied Linguistics and Language Research, 2(3), 238-252. 
[50] Kade, O. (1968). Zufall und Gesetzmäßigkeit in der Übersetzung. VEB Verlag Enzyklopädie.

[51] Kashgary, A. D. (2011). The paradox of translating the untranslatable: Equivalence vs. non-equivalence in translating from Arabic into English. Journal of King Saud University-Languages and Translation, 23(1), 47-57.

[52] Kasprowicz, M. (2010). Handling abbreviations and acronyms in health translation. Translation Journal, 14(2), 52-59.

[53] Keshavarz, M. H., \& Alimadadi Zonoozi, L. (2011). Manipulation of ideology in translation of political texts: A critical discourse analysis perspective. Journal of Language and Translation, 2(1), 1-12.

[54] Khanjan, A., Amouzadeh, M., Eslami Rasekh, A., \& Tavangar, M. (2013). Ideological aspects of translating news headlines from English to Persian. Meta, 58(1), 87-102.

[55] Khodadady, E., \& Lagzian, M. (2013). Textual analysis of an English dentistry textbook and its Persian translation: A schemabased approach. Journal of Studies in Social Sciences, 2(1), 56-63.

[56] Khoury, M. J., Gwinn, M., Yoon, P. W., Dowling, N., Moore, C. A., \& Bradley, L. (2007). The continuum of translation research in genomic medicine: How can we accelerate the appropriate integration of human genome discoveries into health care and disease prevention?. Genetics in Medicine, 9(10), 665-674.

[57] Kiraly, D. (2014). A social constructivist approach to translator education: Empowerment from theory to practice. London: Routledge.

[58] Koller, W. (1995). The concept of equivalence and the object of translation studies. Target. International Journal of Translation Studies, 7(2), 191-222.

[59] Krčmová, M. (2004). A contrastive study of non-fiction (expository) texts. Brno: Czech Science Foundation.

[60] Kuscu, S., \& Unlu, S. (2015). Teaching translation: A suggested lesson plan on translation of advertising through the use of authentic materials. Social and Behavioral Sciences, 199, 407-414.

[61] Larson, M. L. (1984). Meaning-based translation: A guide to cross language equivalence. NY: University Press of America.

[62] Lauscher, S. (2000). Translation quality assessment: Where can theory and practice meet?. The Translator, 6(2), 149-168.

[63] Lederer, M. (2003). The interpretive model. Manchester: St. Jerome.

[64] Leonardi, V. (2000). Equivalence in translation: Between myth and reality. Translation Journal, 4(4), 8942.

[65] Liessmann, K. P. (2006). Platz für die Elite. Die Presse, 1(6), 12-19.

[66] Mahmoodzadeh, M. (2014). Reflections on the development of contrastive domain of second language education: An overview. International Letters of Social and Humanistic Sciences, 3 (17), 1-8.

[67] Merrikhi, P. (2011). The effect of "bilingualism" on Iranian ELT student's "critical thinking ability" (CT). Theory and Practice in Language Studies, 1(10), 1424-1431.

[68] Montafej, J., \& Nemati, A. (2014). Investigating translation competence and its sub-competencies through different viewpoints and proposing PACTE group model as the best one. International Journal of Language Learning and Applied Linguistics World (IJLLALW), 5(1), 16-27.

[69] Mateo, R. M. (2015). Contrastive multimodal analysis of two Spanish translations of a picture book. Procedia-Social and Behavioral Sciences, 212, 230-236.

[70] McGuire, S. (1991). Translation studies. New York: Methuen \& Co. Ltd.

[71] McMorrow, L. (1998). Breaking the Greco-Roman mold in health writing: The many languages. Translation and Medicine, 1(3), 9-15.

[72] Mehrach, M. (2003). Introducing translation as text. Tangiers: Alto-press.

[73] Miao, J. (2000). The limitations of 'equivalent effect'. Perspectives: Studies in Translatology, 8(3), 197-205.

[74] Mirzoyeva, L. (2014). Metaphorical economic terms: Problems of their translation from English into Russian. Procedia-Social and Behavioral Sciences, 136, 169-174.

[75] Montalt, V., \& Davis, M. G. (2007). Health translation step by step. Manchester: St Jerome.

[76] Mora, E., Carrillo, A., Giribet, A., Becerra, A., Lucio, M. J., \& Cobeta, I. (2017). Translation, cultural adaptation, and preliminary evaluation of the Spanish version of the transgender voice questionnaire for male-to-female transsexuals (TVQ $\mathrm{MtF})$. Journal of Voice, 3 (9), 92-101.

[77] Munday, J. (2001). Introducing translation studies, theories and applications. London and New York: Routledge.

[78] Munday, J. (2016). Introducing translation studies: Theories and application. London: Routledge.

[79] Nababan, M. R. (2003). Translation processes, practices and products of professional Indonesian translators. (Unpublished PhD Thesis, Schools of Linguistics and Applied Language Studies, Victoria University of Wellington, New Zealand).

[80] Indonesia, Nababan, N. (2008). Equivalence in translation: Some problem-solving strategies. Retrieved from: https://www.proz.com/translation-articles/articles/2071/1/EQUIVALENCE-IN-TRANSLATION\%3A--SOME-PROBLEMSOLVING-STRATEGIES/print/2071?print=1.

[81] Nation, P. (2010). A contrastive study of current texts translated in Australia. Translation Studies, 22(3), 121-136.

[82] Bandar Lampung, Nerudova, L. (2012). Quality of translation: Approaches and a field survey. (Master thesis, Masaryk University). Retrieved from https://is.muni.cz/th/362710/ff_m/Quality_of_Translation_Approaches_and_a_Field_Survey.pdf

[83] Newmark, P. (1988). A textbook of translation. London: Prentice Hall.

[84] Newmark, P. (1991). About translation. Clevedon: Multilingual Matters.

[85] Newmark, P., \& Newmark, P. (1981). Approaches to translation. Oxford: Pergamon Press.

[86] Nida, E. A. (1964). Toward a science of translation. Leiden: Brill.

[87] Nida, E. A. (1975). Semantic structure and translating. The Bible Translator, 26(1), 120-132.

[88] Nida, E. A. (2004). Toward a science of translating (Vol. 155). Shanghai: Foreign Language Education Press.

[89] Nida, E. A., \& Taber, C.R. (1982). The theory and practice of translation. Leiden: E. J. Brill.

[90] Nord, C. (2007). Translating as a purposeful activity: Functionalist approaches explained. Manchester, UK: St. Jerome Publishing.

[91] Nourzad, L., \& Jabbari, M. J. (2015). A cross-linguistic analysis of English Persian commissives and directives in of mice and men. International Journal of English and Education, 4 (1), 61-73. 
[92] O’Neill, M. (1998). Who makes a better health translator: The healthly knowledgeable linguist or the linguistically knowledgeable health professional? A physician's perspective. In Fischbach, H. (ed.), Translation and medicine (pp. 69-80). Amsterdam/Philadelphia: John Benjamins.

[93] Iran, Ouliaei Nia, H., Changiz, T., \& Sadat Hosseini, T. (2008). Articles: A study of the adequacy and effectiveness of Persi an translations of drug leaflets. Retrieved from Translation Directory Web Site: http://www.translationdirectory.com.

[94] Panahbar, E., \& Moinzade, A. (2011). The study of Persian equivalents for words ending in suffix "-ism." Canadian Social Science, 7(6), 207-212.

[95] Pedersen, A., \& Halliday, T., N. (2009). Translating of health text. Unpublished thesis, Copenhagen business school, Copenhagen, Denmark.

[96] Peterlin, A. P. (2014). Academic discourse in translation: Trainee translators' performance, experience and perception of rhetorical conventions. English for Specific Purposes, 3(6), 60-73.

[97] Pym, A. (2003). Redefining translation competence in an electronic age. In defense of a minimalist approach. Meta: Translators' Journal, 48(4), 481-497.

[98] Pym, A., Malmkjær, K., \& Plana, M. D. M. G. C. (2013). Translation and language learning: An analysis of translation as a method of language learning in primary, secondary and higher education. Retrieved February, $10,2014$. https://www.academia.edu/7801381/Translation_and_Language_Learning.

[99] Qassem, M. A., \& Vijayasarathi, G. (2015). Problematicity of translating cultural idiomatic expressions from English into Arabic. Asia Pacific Translation and Intercultural Studies, 2(1), 57-73.

[100] Rahimi, R. (2004). Alpha, beta and gamma features in translation: Toward the objectivity of testing translation. Translation Studies, 2 (1), 53-64.

[101] Rashidi, N., \& Mavaddat, R. (2014). Strategies used by Persian translators in translating idiomatic expressions from English into Persian: A comparative study based on Gottlieb's Model. Language Learning and Applied Linguistic World, 6(1), 338-358.

[102] Resurreccio, V. (2007). Health translation step by step. Manchester: St Jerome.

[103] Resurreccio, V., \& Davis, M. G. (2007). Health translation step by step. Learning by doing. Manchester: St. Jerome Publishing.

[104] Rezvani, R., \& Nouraey, P. (2014). A comparative study of shifts in english translations of the Quran: A case study on" Yusuf" Chapter. Khazar Journal of Humanities \& Social Sciences, 17(1), 121-128.

[105] Richards, J. C. (2015). Error analysis: Perspectives on second language acquisition. London: Routledge.

[106] Richards, J.C., \& Schmidt, R. (2002). Longman dictionary of language teaching and applied linguistics (3rd ed.). London: Longman.

[107] Rojo, A., Ramos, M., \& Valenzuela, J. (2014). The emotional impact of translation: A heart rate study. Journal of Pragmatics, 7(1), 31-44

[108] Rosdolky, M. (2004). History of medicine part i-brief review of health history. ATA Caduceus, 1(2), 4-8.

[109] Sadeghi, B., \& Farjad, A. (2014). Translation strategies of English idioms by EFL learners: Baker's model in focus. Language Learning and Applied Linguistic World, 6(3), 247-259.

[110] Sadeghi, K. (2011). Classroom translation: The case of Iranian university students. Theory \& Practice in Language Studies, l(9), 44-52.

[111] Sárosi-Márdirosz, K. (2014). Problems related to translation of political texts. Philologica, 6 (2), 159-180.

[112] Sharififar, M. (2007). Cultural differences and semiotic variations in English and Persian: A study of translation problems (Doctoral dissertation, Universiti Sains Malaysia).

[113] Shreve, G. M. (2002). Knowing translation: Cognitive and experiential aspects of translation expertise from the perspective of expertise studies. Translation Studies: Perspectives on an Emerging Discipline, 150-171.

[114] Snell-Hornby, M. (2006). The turns of translation studies: New paradigms or shifting viewpoints? Philadelphia: John Benjamins.

[115] Soualmia, M. (2010). Third-year students' difficulties in translating computing terms from English into Arabic. (Doctoral Dissertation, Mentouri University).

[116] Steinbeck, J. (1937). Of Mice and Men [E-reader version, if applicable]. Retrieved from http://shipk12.org/web/filemgmt.../Steinbeck_-_Of_Mice_and_Men.pdf Retrieved February, 20, 2017.

[117] Stepanova, V. V. (2017). Translation strategies of legal texts: Experimental approach. Procedia-Social and Behavioral Sciences, 23(7), 1201-1207.

[118] Taylor, B. R. (2005). The clinician's guide to health writing. New York: Springer.

[119] UIS. (2007). Book production: Number of titles by UDC classes. Montreal: UNESCO Public Reports.

[120] Ulanska, T. (2015). The role of linguistic factor in translation. Procedia-Social and Behavioral Sciences, 1(91), $2585-2587$.

[121] Ulvydiené, L. (2014). Psychology of translation in cross-cultural interaction. Procedia-Social and Behavioral Sciences, 11(6), 217-226.

[122] Van Hoof, H. (1993). Histoire de la traduction médicale en Occident. Cahiers de l'Institut de linguistique de Louvain, 19(1-2), $75-125$.

[123] Van Hoof, H. (1998). Mini-study of English and French. Translation and Medicine, 4(9), 26-32.

[124] Vinay, J. P., \& Darbelnet, J. (1995) Comparative stylistics of French and English: A methodology for translation. Philadelphia: John Benjamins.

[125] Wilss, W. (1982). The science of translation: Problems and methods. Philadelphia: John Benjamins.

[126] Ying, L., \& Yumei, Z. (2010). Lexis in Chinese-English translation of drug package inserts: Corpus-based error analysis and its translation strategies. International Journal of Biohealth Science, 6 (4), 344-350.

[127] Yinhua, X. (2011). Equivalence in translation: Features and necessity. International Journal of Humanities and Social Science, $1(10), 169-171$.

[128] Yousofi, N. (2014). Describing the errors in the translations of Iranian novice English translators. Procedia-Social and Behavioral Sciences, 9(8), 1952-1958. 
[129] Zamani, M. (2013). Persian translation of directive and expressive speech acts in death of a salesman. A streetcar named desire, and mourning becomes electra. (Master Thesis, Sheikhbahaee University of Isfahan, Isfahan, Iran).

Maryam Gharedaghi received her BA in English Translation from Islamic Azad University North Tehran Branch and her MA in the same field from Islamic Azad University Parand Branch. She has more than ten years of work experience as the translator of health. And currently she is the editor and translator of medical news and health news.

Razieh Eslamieh (corresponding author) has completed her PhD program in English Language and Literature in Islamic Azad University Tehran Central Branch in 2011. She has been Exam Editor and Exam Designer in Payam-e-Noor University, from 2005 to 2015. She has also been Senior Lecturer for M.A. Program in Islamic Azad University Tehran Central Branch since 2011. However, she is the assistant professor in Islamic Azad University Parand Branch where she teaches MA and BA courses of English language and literature as well as English Language Translation. She has so far translated a few books including but not limited to Girls at War and Other Stories from English to Farsi (Iran, Tehran: Dabizesh Publication, 2017), Advertisement also translated from English to Farsi, (Iran, Tehran: Karevan Publication, 2005). Her recent book is Jeremy Munday's Introducing Translation Studies: Theory and Practice Reader (Iran, Tehran: Dabizesh Publication, 2017). Her main research interests are postcolonialism, cultural studies, minimalism and flash fiction on the one hand and translation theories on the other hand.

Hamid Reza Shahidi is currently assistant professor and board certified member in Islamic Azad University Garmsar Branch. He received his PhD in Teaching and has been active teaching MA and BA courses related to teaching and linguistics in different branches of Islamic Azad University as well as state universities. He has national and international publications. 